\title{
A non-glycosylated form of pulmonary surfactant protein A appears in rat amniotic fluid
}

\author{
K. Sakai, T. Kohri, M.N. Kweon, Y. Kishino
}

\begin{abstract}
A non-glycosylated form of pulmonary surfactant protein A appears in rat amniotic fluid. K. Sakai, T. Kohri, M.N. Kweon, Y. Kishino. OERS Journals Ltd 1994.

ABSTRACT: Surfactant protein A (SP-A) is a family of glycoproteins that have a triplet with 26, 32 and $36 \mathrm{kDa}$ under reducing conditions in rat lung. We wanted to evaluate the SP-A forms in amniotic fluid of pregnant rats compared to those found in rat lungs.

By Western blot analysis, glycosylated SP-A, was not found in the amniotic fluid in contrast to the pulmonary surfactant triplet SP-A, which comprises a $26 \mathrm{kDa}$ protein and its glycosylated 32 and $36 \mathrm{kDa}$ forms. The SP-A concentration in amniotic fluid was barely detectable at 18 days of gestation $\left(20 \pm 12 \mathrm{ng} \cdot \mathrm{ml}^{-1}\right)$, and then increased and reached $700 \pm 333 \mathrm{ng} \cdot \mathrm{ml}^{-1}$ at the final gestational day 21 , as determined by an enzyme-linked immunoabsorbent assay. Immunohistochemically, SPA was found in some epithelial cells of larger respiratory bronchi, but not, or to a lesser degree, in smaller respiratory bronchi at gestational day 18. At 21 days of gestation, SP-A was detected in bronchial and bronchiolar nonciliated epithelial Clara cells, alveolar epithelial type II cells and some alveolar macrophages. The ratio of the 26, 32 and $36 \mathrm{kDa} \mathrm{SP}-\mathrm{A}$ forms in bronchoalveolar, bronchobronchiolar and tracheal lavage fluids prepared from adult rats was 6:29:65, 84:5:11 and 100:0:0, respectively.
\end{abstract}

These findings show the presence of a non-glycosylated SP-A in rat amniotic fluid. This may reflect the increased ratio of non-glycosylated SP-A to bronchoalveolar, bronchobronchiolar and tracheal lavage fluids, respectively. Eur Respir J., 1994, 7, 88-93.

\author{
Dept of Nutrition, School of Medicine, \\ The University of Tokushima, Tokushima, \\ Japan. \\ Correspondence: K. Sakai \\ Dept of Nutrition \\ School of Medicine \\ The University of Tokushima \\ Tokushima 770 \\ Japan \\ Keywords: Amniotic fluid \\ gestation \\ glycosylation \\ immunohistochemistry \\ surfactant protein $\mathrm{A}$ \\ rat \\ Received: February 21993 \\ Accepted July 131993
}

Pulmonary surfactant, a specific lung lipoprotein, which is composed of phospholipids, neutral lipids and proteins, is produced and secreted into the airway lumen by alveolar type II cells, to lower the surface tension at the air-fluid interface of the airways [1, 2]. Phospholipids in human amniotic fluid during pregnancy have been used to estimate foetal lung maturation and as a predictor of respiratory distress syndrome (RDS), since their composition in amniotic fluid reflects the amount of pulmonary surfactant in lung fluids $[3,4]$. To date, at least four pulmonary surfactant specific proteins, surfactant proteins A (SP-A), B (SP-B), C (SP-C), and D (SP-D), have been characterized and their functions have been reported [5]. SP-A is the most abundant and enhances the surface tension-lowering properties of phospholipid mixtures containing the hydrophobic proteins SP-B and SP-C [6]. SP-A also plays an important role in regulating surfactant homeostasis [7], and alveolar macrophage functions [8-10]. SP-A contains asparagine-linked oligosaccharide units at the C-terminus, which confer a triplet with a molecular mass of 26, 32 and $36 \mathrm{kDa}$ under reducing conditions in rats [11]. The oligosaccharide moiety of SP-A is involved in $\mathrm{Ca}^{2+}$-dependent aggregation of phospholipid vesicles, in connection with the formation of the tubular myelin lattice that is the pri- mary structure after secreting pulmonary surfactant into the airway spaces [12]. As the foetal lung develops, SPA also appears in human amniotic fluid, and is correlated with the presence of phospholipids. Therefore, SP-A is also useful in the prenatal assessment of lung maturity and as a predictor of RDS [13-15]. Although surfactant lipids and SP-A have important functions in the lung, it is not known whether they have physiological functions in amniotic fluid.

The purpose of this study was to investigate whether or not the profiles of SP-A forms in amniotic fluid of pregnant rats are identical to those in the lung. We describe here that SP-A in amniotic fluid is composed of the non-glycosylated form and is not associated with oligosaccharide moieties. We also discuss the origin of non-glycosylated SP-A in amniotic fluid, on the basis of biochemical and immunohistochemical studies.

Materials and methods

\section{Animals and sample preparations}

Specific pathogen-free 11 week old Fisher rats, from Japan SLC Inc. (Shizuoka, Japan), were mated and the 
gestational age was initially determined by designating the presence of a sperm positive vaginal smear as day 0 . The rats were given food and water ad libitum and housed in an air-conditioned room at $22 \pm 2{ }^{\circ} \mathrm{C}$. Foetuses at $18,19,20$ and 21 days of gestation were delivered individually through a hysterotomy, after anaesthetizing pregnant rats with an intraperitoneal injection of sodium pentobarbital. On each gestational day amniotic fluid, was collected by inserting a needle into the amniotic cavity.

\section{Preparation of bronchoalveolar, bronchobronchiolar and tracheal lavage fluids}

All lavage fluids were obtained from 11 week old male Fisher rats (Japan SLC). Bronchoalveolar lavage was performed as described previously [16]. Rats were anaesthetized by an intraperitoneal injection of sodium pentobarbital and killed by cutting both renal arteries. A cannula was inserted into the trachea and placed on the terminus of the inferior trachea. The lungs were washed twice with $5 \mathrm{ml}$ of sterile saline at $37^{\circ} \mathrm{C}$. Bronchobronchiolar lavage was performed in the same manner, except that $300 \mu \mathrm{l}$ of saline was instilled. Loci of the bronchobronchiolar lavage were preliminarily checked by serial lung sections about $1 \mathrm{~mm}$ thick, immediately after instillation of saline containing $0.4 \%$ Indian ink. The coloured regions of the lungs were the respiratory bronchi and bronchioles and some areas of the alveoli adjacent to bronchioles. Tracheal lavage fluid was obtained by two passages of $100 \mathrm{ul}$ of saline through the duct of the excised trachea. The lavage fluids were collected and centrifuged at $400 \times \mathrm{g}$ for $10 \mathrm{~min}$ at $4^{\circ} \mathrm{C}$ to remove airway cells, and the resultant supernatants were stored at $-80^{\circ} \mathrm{C}$ until use.

\section{Preparation of SP-A and antibody against SP-A}

Pulmonary surfactant and SP-A were purified from rat bronchoalveolar lavage fluid [8]. The antibody against SP-A raised in rabbits has been described in detail [8]. Sulphosuccinimidyl-6-(biotinamide) hexanoate (NHS-LCbiotin, Pierce Chemical Co., Rockford, IL, USA) was used to introduce biotin moieties into the antibody. One hundred microlitres of immunoglobulin $\mathrm{G}(\mathrm{IgG})$ fraction $\left(10 \mathrm{mg} \cdot \mathrm{ml}^{-1}\right)$ dissolved in $0.1 \mathrm{M}$ carbonate buffer, $\mathrm{pH}$ 8.5 , was mixed with $5 \mu \mathrm{l}$ of NHS-LC-biotin $\left(4 \mathrm{mg} \cdot \mathrm{ml}^{-1}\right.$ in the same buffer) and incubated at $4^{\circ} \mathrm{C}$ for $2 \mathrm{~h}$. Nonreacted NHS-LC-biotin was removed by passage through a NAP-10 column containing Sephadex G-25 Medium (Pharmacia LKB Biotechnology AB, Uppsala, Sweden).

\section{SP-A level in amniotic fluids}

The SP-A level in amniotic fluids was determined using a sensitive enzyme-linked immunosorbent assay (ELISA) and anti-rat SP-A rabbit IgGs labelled with and without biotin. Each well of an untreated polystyrene microtitre plates (Becton Dickinson Labware, Lincoln Park, NJ,
USA) was coated with $100 \mu$ of anti-SP-A IgG (20 $\mu \mathrm{g} \cdot \mathrm{ml}^{-1}$ diluted with $50 \mathrm{mM}$ carbonate buffer, $\mathrm{pH}$ 9.6) by incubation overnight at $4^{\circ} \mathrm{C}$, then blocked with $5 \%$ skimmed milk in $25 \mathrm{mM}$ Tris- $\mathrm{HCl}$ buffer, $\mathrm{pH} 7.4$, containing $0.14 \mathrm{M} \mathrm{NaCl}, 5 \mathrm{mM} \mathrm{KCl}$ (TBS) and $0.1 \% \mathrm{NaN}_{3}$ for $1 \mathrm{~h}$ at room temperature. The wells were washed three times with TBS containing $0.5 \%$ Tween 20 (TBS$\mathrm{T})$, then incubated with $100 \mu \mathrm{l}$ of purified rat SP-A standard $\left(0.1-5 \mathrm{ng} \cdot \mathrm{ml}^{-1}\right)$ or various dilutions of samples in $20 \mathrm{mM}$ Tris- $\mathrm{HCl}$ buffer, $\mathrm{pH} 7.4$, containing $10^{-5} \mathrm{M}$ phenyl methyl sulphonyl fluoride (PMSF), $10^{-5} \mathrm{M}$ leupeptin and $2 \mathrm{mM}$ ethylene diamine tetra-acetic acid (EDTA) for 1 $\mathrm{h}$ at room temperature. The wells were washed and 100 $\mu \mathrm{l}$ of biotinylated anti-SP-A IgG $\left(20 \mu \mathrm{g} \cdot \mathrm{ml}^{-1}\right)$ in $5 \mathrm{mM}$ Tris- $\mathrm{HCl}, \mathrm{pH} 7.4$ was then added to each well, and incubated for $1 \mathrm{~h}$ at room temperature. After three washes with TBS-T, the wells were incubated with the avidinbiotin complex (Vectastain ABC Elite Kit, Vector Laboratories, Burlingame, CA, USA) for $30 \mathrm{~min}$ at room temperature. The wells were washed with TBS-T and $100 \mu$ of peroxidase substrate containing $0.02 \% 3,3^{\prime}, 5,5^{\prime}-$ tetramethylbenzidine, $0.01 \%$ hydrogen peroxide (TMB Microwell Peroxidase Substrate System, Kirkegaard \& Perry Laboratory Inc., Gaithersburg, MD, USA) was added to each well, followed by incubation for $20 \mathrm{~min}$ at room temperature. The reaction was terminated by adding $100 \mu \mathrm{l}$ of $1 \mathrm{M}$ phosphoric acid to the wells. The absorbance at $450 \mathrm{~nm}$ was read in a Hitachi F-3010 multiplate reader.

\section{Electrophoresis and Western blot analysis}

Preparations of amniotic fluid were analysed by electrophoresis on $12.5 \%$ polyacrylamide gel containing $0.1 \%$ sodium dodecyl sulphate (SDS), by the method of LAEMMLI [17], under reducing conditions, and the gels were then transferred electrophoretically to nitrocellulose membranes. The membranes were soaked in $3 \%$ bovine serum albumin (BSA) to block nonspecific binding, and then incubated for $2 \mathrm{~h}$ at room temperature with an antibody (4 $\mu \mathrm{g} \cdot \mathrm{ml}^{-1}$ ) against the purified SP-A, according to the method of TowBIN et al. [18]. The polyacrylamide gels were also stained with silver, and SDS-polyacrylamide low range standards (Pharmacia) were used as molecular weight markers.

\section{Protein measurement}

The protein concentration was measured with bicinchoninic acid protein assay reagent (Pierce) by the method of Sмiтн et al. [19].

\section{Immunohistochemical staining}

Lungs of foetal rats were fixed with $10 \%$ buffered formalin, $\mathrm{pH} \mathrm{7.2,} \mathrm{for} \mathrm{a} \mathrm{day} \mathrm{at} 4^{\circ} \mathrm{C}$ and embedded in paraffin. Lung sections of $4 \mu \mathrm{m}$ thickness were placed on glass slides and immunohistochemically stained using 
the avidin-biotin-peroxidase complex method [20]. The slides were deparaffinized and soaked in $0.3 \%$ hydrogen peroxide in absolute methanol for $30 \mathrm{~min}$ at room temperature. After hydration and a rinse in phosphate buffered saline (PBS; $10 \mathrm{mM}$ phosphate buffer, $\mathrm{pH}$ 7.2, containing $0.85 \% \mathrm{NaCl}$ ), the sections were treated with normal goat serum at a 1:60 dilution for $20 \mathrm{~min}$ at room temperature to reduce nonspecific staining, and then incubated at $4^{\circ} \mathrm{C}$ overnight, with $4 \mu \mathrm{g} \cdot \mathrm{ml}^{-1}$ of antibody against SP-A in PBS containing 0.1\% BSA in a moist chamber. The sections were rinsed in PBS and incubated for 50 min at room temperature in a 1:200 dilution of biotinylated goat anti-rabbit IgG (Vectastain ABC Kit, Vector Laboratories). Following a rinse in PBS, the sections were incubated for $60 \mathrm{~min}$ at room temperature in the avidin-biotin complex, rinsed in PBS, stained for $5 \mathrm{~min}$ with $50 \mathrm{mM}$ Tris- $\mathrm{HCl}$, pH 7.6, containing $0.1 \%$ 3,3'diaminobenzidine tetrahydrochloride, $0.02 \%$ hydrogen peroxide and $0.65 \% \mathrm{mg} \cdot \mathrm{ml}^{-1}$ sodium azide. After washing with PBS, the sections were counterstained for 10 min with $1 \%$ methyl green, dehydrated and mounted.

Controls were prepared by using the conditions described above except that nonimmunized rabbit $\mathrm{IgG}$ was used instead of the primary antibody.

\section{Results}

\section{SP-A in rat amniotic fluid}

The presence of SP-A in the amniotic fluid of gestational female rats was determined by Western blotting (fig. 1a) and ELISA (fig. 1b). At 19 days of gestation,

a)

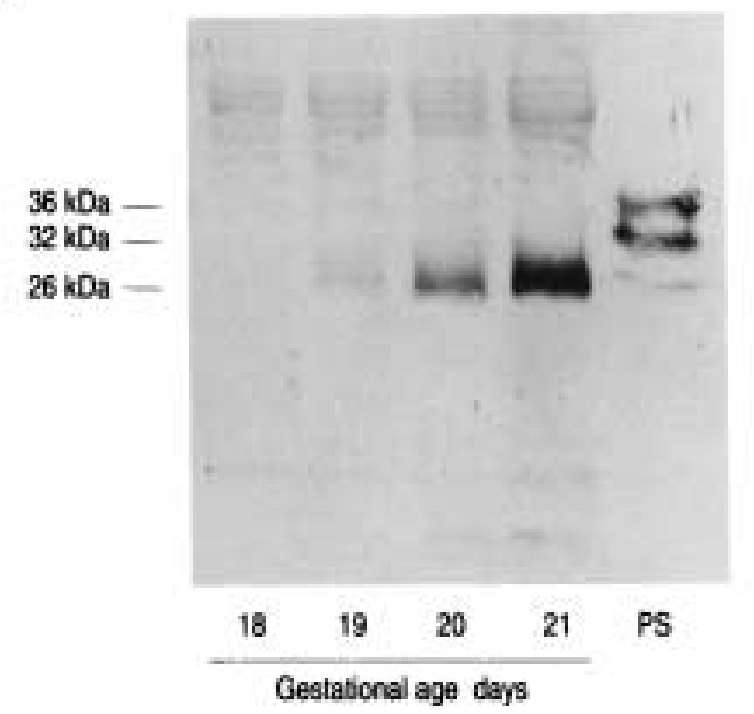

Western blotting revealed an immunoreactive SP-A band, with a molecular mass of $26 \mathrm{kDa}$, associated with no additional oligosaccharide moieties. This signal became more marked as the gestational days proceeded. Glycosylated forms of SP-A, 32 and $36 \mathrm{kDa}$, as can be seen in pulmonary surfactant, were undetectable throughout the gestational period. SP-A was barely detectable in amniotic fluid at 18 days of gestation $\left(20 \pm 12 \mathrm{ng} \cdot \mathrm{ml}^{-1}\right)$, after which it dramatically increased, reaching $700 \pm 333$ $\mathrm{ng} \cdot \mathrm{ml}^{-1}$ at the final gestational day 21 .

\section{Immunohistochemical staining of foetal lung}

Foetal lung section at gestational day 18 contained a few epithelial cells positive to antibody against SP-A in larger respiratory bronchi, but few or none in smaller respiratory bronchi (fig 2A). As shown in figure 2B, the alveolar wall was more developed at gestational day 21 than day 18, and almost all alveolar spaces, although narrow, were open. The respiratory bronchi and bronchioles showed intense staining with the antibody in nonciliated cells, indicating that they were Clara cells. Immunopositive cells were also distributed in the alveolar walls, where alveolar epithelial type II cells and some alveolar macrophages were stained, but they were less immunoreactive than the respiratory Clara cells. No reaction products were seen in control sections prepared using non-immunized rabbit IgG as the primary antibody (data not shown).

\section{Immunoblotting of various lavage fluids}

Figure 3a shows Western blot profiles indicating three forms $(26,32$ and $36 \mathrm{kDa})$ of SP-A in bronchoalveolar,

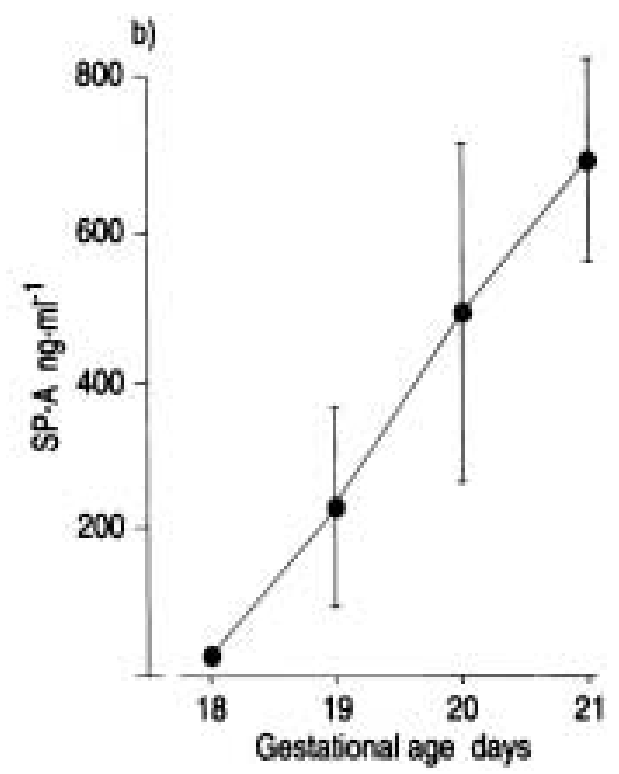

Fig. 1. - Western blots (a) and SP-A content (b) in amniotic fluid of rats at late gestation (17-21 days). Amniotic fluid was collected by insertion of a needle into the amniotic cavity and added to an equal volume of SDS-preparation buffer. Sample preparations of each amniotic fluid $(10 \mu \mathrm{l})$ and rat pulmonary surfactant (PS) (10 ng protein) were separated by 12.5\% SDS-polyacrylamide gel electrophoresis under reducing conditions. The gels were then transferred electrophoretically to a nitrocellulose membrane and developed with $4 \mu \mathrm{g} \cdot \mathrm{ml}^{-1} \mathrm{of}$ antibody against rat SPA. The content of SP-A in amniotic fluid was determined by ELISA as described in "Materials and methods". The data represent means \pm sD from six to eleven separate assays in each point. SP-A: surfactant protein-A; SDS: sodium dodecyl sulphate; ELISA: enzyme-linked immunosorbent assay. 

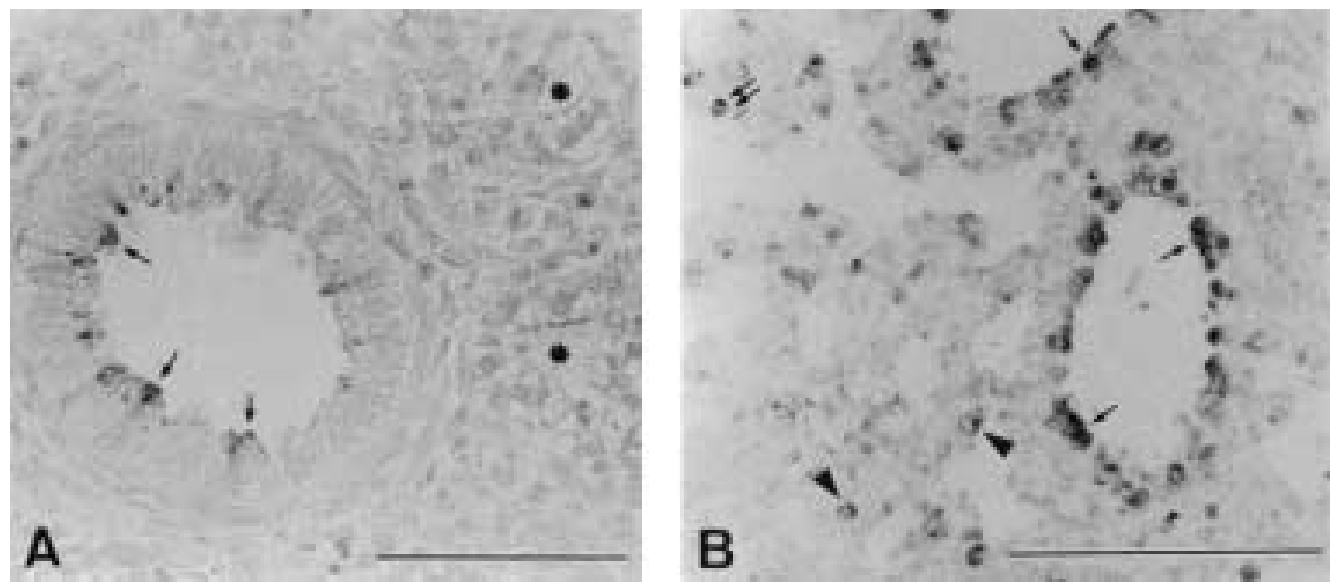

Fig. 2. - Immunohistochemical staining of the foetal lung with antibody against surfactant protein-A (SP-A). A) Lung section at 18 days of gestation. Lung cells are not well differentiated into identifiable cell types. Weakly immunoreactive products are seen in some epithelial cells (arrows) of the larger respiratory bronchus, but not or at lower levels in smaller respiratory bronchi (asterisks). B) Lung section of gestational days 21. Intense deposits of immunoreactive staining are seen in bronchiolar epithelial Clara cells (arrows). Alveolar type II cells (arrow heads) and some alveolar macrophages (double arrow) in the alveoli are also positive to the antibody, but show less immunoreactivity than that of respiratory Clara cells. (Bars=100 $\mu \mathrm{m})$.

a)

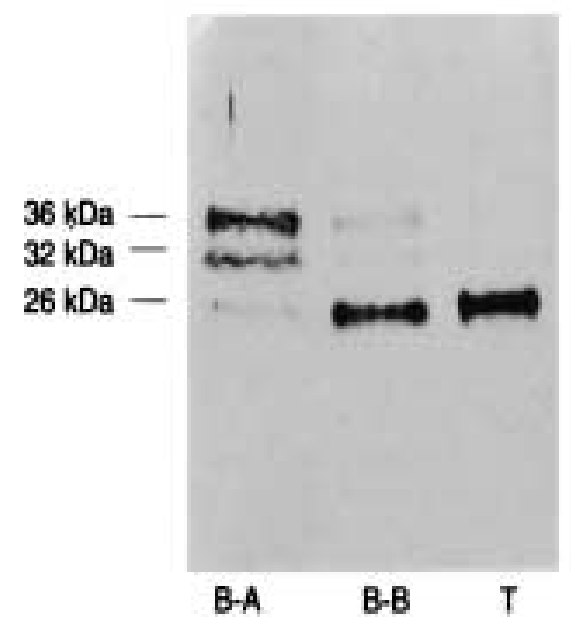

b)

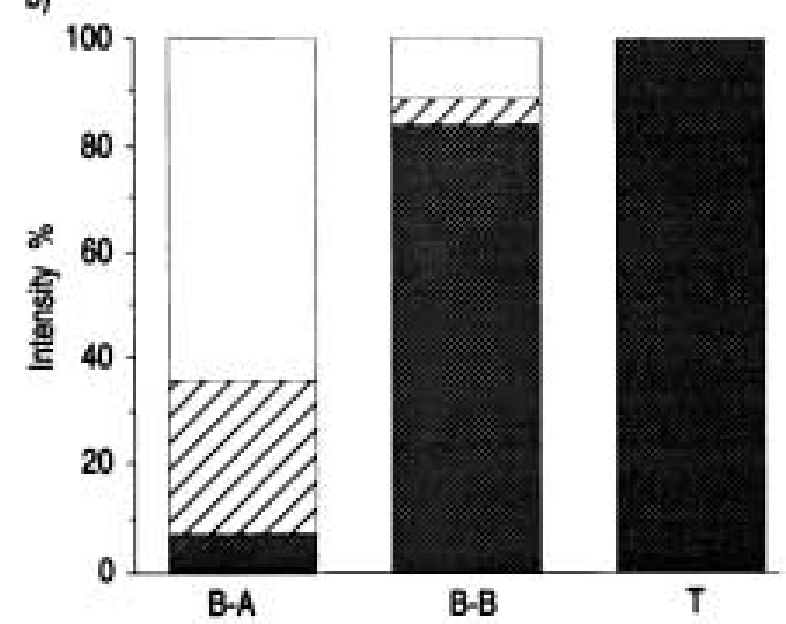

Fig. 3. - Western blots (a) and corresponding densitometric scanning (b) of surfactant protein-A (SP-A) in bronchoalveolar (B-A), bronchobronchiolar (B-B), and tracheal (T) lavage fluids. Each lavage was performed as described in "Materials and methods". Sample preparations (10 pl) were seperated by $12.5 \%$ SDS-polyacrylamide gel electrophoresis under reducing conditions. The gels were then transferred to a nitrocellulose membrane and developed with antibody against SP-A in the same manner as that described in the legend to figure 1a. The ratio of the 26, 32 and $36 \mathrm{kDa}$ forms of SP-A in each lane of the blotted membranes was quantified by scanning densitometry and the results are expressed as the percentages of the total intensity in each lane. $\square: 36 \mathrm{kDa} ; \square: 32 \mathrm{kDa} ; \square: 26 \mathrm{kDa}$. SDS: sodium dodecyl sulphate.

bronchobronchiolar, and tracheal lavage fluids. Values of three forms of SP-A in each lavage fluid were obtained by densitometrically scanning the immunoblotted membranes, as shown in figure $3 \mathrm{~b}$. There were large amounts of glycosylated SP-A (32 kDa, 29\%; $36 \mathrm{kDa}, 65 \%)$ and a small quantity of the non-glycosylated form $(26 \mathrm{kDa}$, $6 \%$ ) in bronchoalveolar lavage fluid. In contrast to the bronchoalveolar lavage fluid, bronchobronchiolar lavage fluid was greatly enriched with non-glycosylated SP-A (26 kDa, 84\%), but poor in forms associated with oligosacharide units $(32 \mathrm{kDa}, 5 \% ; 36 \mathrm{kDa}, 11 \%)$. In tracheal lavage fluid, only non-glycosylated SP-A was detectable.

\section{Discussion}

In this study, Western blotting showed that the $26 \mathrm{kDa}$ non-glycosylated SP-A was first detectable in rat amniotic fluid at gestational day 19, and increased with the progression of gestation. No SP-A forms associated with oligosaccharide moieties were detected throughout the gestational period. By means of an ELISA, the SP-A level in amniotic fluid was barely detected at gestational day $18\left(20 \pm 12 \mathrm{ng} \cdot \mathrm{ml}^{-1}\right)$, then increased and reached $700 \pm 333 \mathrm{ng} \cdot \mathrm{ml}^{-1}$ at the final gestational day 21 . The pulmonary surfactant isolated from rat bronchoalveolar lavage fluid contains a triplet of SP-A, 26, 32 and $36 \mathrm{kDa}$, under 
reducing conditions, which is attributed to varying levels of glycosylation of the $26 \mathrm{kDa}$ form, and each of the three forms of SP-A has the same amino acid sequence [11]. SP-A is produced and secreted into the airway lumen by alveolar epithelial type II cells and bronchial and bronchiolar epithelial Clara cells [8, 21-23].

Pulmonary surfactant lipids in human amniotic fluid are useful for predicting RDS, because the phospholipids, especially saturated phosphatidylcholine, phosphatidylglycerol and phosphatidylinositol, contribute to the amount of pulmonary surfactant in lung fluid. SP-A in human amniotic fluid has also been assessed as a predictor of RDS [13-15]. However, it is unclear whether surfactant lipids and proteins have physiological functions in amniotic fluid. Glycosylation of SP-A is located at the C-terminal domain that contains a sequence similar to carbohydrate binding lectins [24]. Oligosaccharide moieties of SP-A are required for aggregation of phospholipid vesicles, that is relevant to the formation of the tubular myelin lattice as a primary structure to serve a monolayer in the alveolar epithelium [12].

Recently, we found that rat pulmonary surfactant is an endogenous inhibitor of a novel serine protease, that is localized exclusively in respiratory epithelial Clara cells $[25,26]$ and activates the infectivity of influenza virus and Sendai virus, resulting in suppression of the infection of these viruses in the lungs in vitro and in vivo [27]. It is debatable whether pulmonary surfactant and SP-A have similar functions in the amniotic cavity.

We measured the SP-A level in rat amniotic fluid using a sensitive ELISA, which showed an increase with advancing gestation after the initial appearance on day 18 , but which was much lower than the level in human amniotic fluid, as reported by KUROKI et al. [28] and PRYHUBER et al. [15]. For example, the content of SP-A in rat amniotic fluid at the final gestational day 21 was $700 \pm 333$ $\mathrm{ng} \cdot \mathrm{ml}^{-1}$, which is about twentyfold lower than that in human amniotic fluid at the final gestational week [15, 28]. This result suggests that the flow quantity of SP$\mathrm{A}$ into the amniotic cavity may be lower in rats than in humans, and that SP-A may be more rapidly metabolized in rat than human amniotic fluid.

Components of pulmonary surfactant appear in the amniotic fluid after passing through the respiratory tract. To approach the mechanisms of the appearance of only the non-glycosylated form of SP-A in rat amniotic fluid, we analysed the molecular mass of the SP-A forms in tracheal, bronchobronchiolar and bronchoalveolar lavage fluids. The profiles of the SP-A forms among these lavage fluids differed. Bronchoalveolar lavage fluid contained a triplet of SP-A that was composed of abundant glycosylated forms (32 and $36 \mathrm{kDa}, 29$ and $65 \%$, respectively) and a small amount of the nonglycosylated form $(26 \mathrm{kDa}, 6 \%)$, which is similar to SPA purified from the pulmonary surfactant. In contrast to the bronchoalveolar lavage fluid, enriched SP-A of non-glycosylated form (26 kDa, 84\%) and small amount of glycosylated forms ( 32 and $36 \mathrm{kDa}, 5$ and $11 \%$, respectively) were detected in bronchobronchiolar lavage fluid. Tracheal lavage fluid contained only non-glycosylated SP-A. Among respiratory cells it has been reported that
SP-A is synthesized and secreted by nonciliated epithelial Clara cells, but not by the other cells, including ciliated epithelial, goblet and subepithelial cells [8, 21-23]. Furthermore, there has been no report of cells that synthesize SP-A in the trachea and the other organs and tissues, except for the lung.

The present findings suggest that the non-glycosylated SP-A in rat amniotic fluid may be related to the different profiles of SP-A forms in the lavage fluids of the trachea, bronchobronchioles and bronchoalveoli, and that deglycosylation of SP-A may occur during passage through the tracheal and/or respiratory tract. Immuno-histochemical staining of foetal lung sections at 21 days of gestation with anti-rat SP-A antibody showed that the immunoreactive intensity of Clara cells was higher than those of alveolar type II cells. Alveolar macrophages were also stained with the antibody at this stage. However, we suppose that the staining of alveolar macrophages was due to the uptake and not the synthesis of SP-A, since Broers et al. [29], and Phelps and Floros [30], failed to detect messenger ribonucleic acid (mRNA) encoding SP-A in alveolar macrophages by in situ hybridization and ribonucleic acid (RNA) blot analysis, respectively.

The new finding of our study is that only the nonglycosylated form of SP-A is present in the amniotic fluid of pregnant rats. This does not conflict with the increased ratio of non-glycosylated SP-A found in bronchobronchiolar and tracheal lavage fluid, respectively, as this is the route of SP-A before it reaches the amniotic cavity. Further studies are needed to understand the precise mechanisms of this transfer. We believe that the approach taken in this study helped clarify the SP-A functions in amniotic fluid and supports assessments of foetal lung development in gestational rats.

Acknowledgements: The authors thank S. Sakamoto and H. Manabe, Department of Nutrition, School of Medicine, The University of Tokushima, Japan, for their helpful assistance with mating of rats.

\section{References}

1. Rooney SA. - The surfactant system and lung phospholipid biochemistry. Am J Respir Dis 1985; 131: 439-460.

2. Van Golde LMG, Batenburg JJ, Robertson B. - The pulmonary surfactant system: biochemical aspects and functional significance. Physiol Rev 1988; 68: 374-455.

3. Donald IR, Freeman RK, Goebelsmann U, Chan WH, Nakamura RM. - Clinical experience with the amniotic fluid lecithin/sphingomyelin ratio. I. Antenatal prediction of pulmonary maturity. Am J Obstet Gynecol 1973; 115: 547-552.

4. Hallman M, Kulovich M, Kirkpatrick E, Sugarman RG, Gluck L. - Phosphatidylinositol and phosphatidylglycerol in amniotic fluid: indices of lung maturity. Am J Obstet Gynecol 1976; 125: 613-617.

5. Hawgood S, Shiffer K. - Structures and properties of the surfactant-associated proteins. Annu Rev Physiol 1991; 53: 375-394.

6. Cockshutt AM, Weitz J, Possmayer F. - Pulmonary surfactant-associated protein A enhances the surface activity 
of lipid extract surfactant and reverses inhibition by blood proteins in vitro. Biochemistry 1990; 29: 8424-8429.

7. Wright JR, Dobbs LG. - Regulation of pulmonary surfactant secretion and clearance. Annu Rev Physiol 1991; 53: 395-414.

8. Sakai K, Kweon MN, Kohri T, Kishino Y. - Effects of pulmonary surfactant and surfactant protein A on phagocytosis of fractionated alveolar macrophages: relationship to starvation. Cell Mol Biol 1992; 38: 123-130.

9. Tenner AJ, Robinson SL, Borchelt J, Wright JR. Human pulmonary surfactant protein (SP-A), a protein structurally homologous to C1q, can enhance FcR- and CR1-mediated phagocytosis. J Biol Chem 1989; 264: 13923-13928.

10. Van Iwaarden F, Welmers B, Verhoef J, Haagsman HP, van Golde LMG. - Pulmonary surfactant protein A enhances the host-defense mechanism of rat alveolar macrophages. Am J Respir Cell Mol Biol 1990; 2: 91-98.

11. Hawgood S, Benson BJ, Hamilton RL Jr. - Effects of a surfactant-associated protein and calcium ions on the structure and surface activity of lung surfactant lipids. Biochemistry 1985; 24: 184-190.

12. Haagsman HP, Elfring RH, van Buel BLM, Voorhout WF. - The lung lectin surfactant protein A aggregates phospholipid vesicles via a novel mechanism. Biochem J 1991; 275: 273-276.

13. Hallman M, Arjomaa P, Mizumoto M, Akino T. Surfac-tant proteins in the diagnosis of fetal lung maturity. I. Predictive accuracy of the $35 \mathrm{kD}$ protein, the lecithin/sphingomyelin ratio, and phosphatidylglycerol. Am J Obstet Gynecol 1988; 158: 531-535.

14. Paciga JE, Shelly SA, Paterson JE, Knuppel RA, Scerbo JC, Balis JU. - Lung surfactant-associated glycoproteins and proteolipids in human amniotic fluids evaluated by dot immunoblotting assays. Ann Clin Lab Sci 1988; 18: 141-147.

15. Pryhuber GS, Hull WM, Fink I, McMahan MJ, Whitsett JA. - Ontogeny of surfactant proteins A and B in human amniotic fluid as indices of fetal lung maturity. Pediatr Res 1991; 30: 597-605.

16. Sakai K, Moriya H, Ueyama A, Kishino Y. - Heterogeneity of fractionated alveolar macrophages in starved rats. Nutr Res 1990; 10: 1141-1149.

17. Laemmli UK. - Cleavage of structural proteins during the assembly of the head of bacteriophage $\mathrm{T}_{4}$. Nature 1970; 227: 680-685.

18. Towbin H, Staehelin T, Gordon J. - Electrophoretic transfer of proteins from polyacrylamide gels to nitrocellulose sheets: procedure and some applications. Proc Natl Acad Sci USA 1979; 76: 4350-4354.
19. Smith PK, Krohn RI, Hermanson GT, et al. - Measurement of protein using bicinchoninic acid. Anal Biochem 1985; 150: 76-85.

20. Hsu S-M, Raine L, Fanger H. - Use of avidin-biotinperoxidase complex $(\mathrm{ABC})$ in immunoperoxidase techniques: a comparison between $\mathrm{ABC}$ and unlabeled antibody (PAP) procedures. J Histochem Cytochem 1981; 29: 577-580.

21. Coalson JJ, Winter VT, Martin HM, King RJ. - Colloidal gold immunoultrastructural localization of rat surfactant. Am Rev Respir Dis 1986; 133: 230-237.

22. Walker SR, Williams MC, Benson B. - Immunocytochemical localization of the major surfactant apoproteins in type II cells, Clara cells and alveolar macrophages of rat lung. J Histochem Cytochem 1986; 34: 1137-1148.

23. Voorhout WF, Veenendaal T, Kuroki Y, Ogasawara Y, van Golde LMG, Geuze HJ. - Immunohistochemical locali-zation of surfactant protein D (SP-D) in type II cells, Clara cells, and alveolar macrophages of rat lung. J Histochem Cytochem 1992; 40: 1589-1597.

24. Sano K, Fisher J, Mason RJ, et al. - Isolation and sequence of a cDNA clone for the rat pulmonary surfactant-associated protein (PSP-A). Biochem Biophys Res Commun 1987; 144: 367-374.

25. Kido H, Yokogoshi Y, Sakai K, et al. - Isolation and characterization of a novel trypsin-like protease found in rat bronchiolar epithelial Clara cells. A possible activator of the viral fusion glycoprotein. J Biol Chem 1992; 267: 13573-13579.

26. Sakai K, Kawaguchi Y, Kishino Y, Kido H. - Electron immunohistochemical localization in rat bronchiolar epithelial cells of tryptase Clara which determines the pneumotropism and pathogenicity of Sendai virus and influenza virus. J Histochem Cytochem 1993; 41: 89-93.

27. Kido H, Sakai K, Kishino Y, Tashiro M. - Pulmonary surfactant is a potential endogenous inhibitor of proteolytic activation of Sendai virus and influenza virus. FEBS Letters 1993; 322: 115-119.

28. Kuroki Y, Takahashi H, Fukada Y, et al. - Two-site "simultaneous" immunoassay with monoclonal antibodies for the determination of surfactant apoproteins in human amniotic fluid. Pediatr Res 1985; 19: 1017-1020.

29. Broers JLV, Jensen SM, Travis WD, et al. - Expression of surfactant associated protein-A and Clara cell 10 kilodalton mRNA in neoplastic and non-neoplastic human lung tissue as detected by in situ hybridization. Lab Invest 1992; 66: 337-346.

30. Phelps DS, Floros J. - Localization of surfactant protein synthesis in human lung by in situ hybridization. Am Rev Respir Dis 1988; 137: 939-942. 